\title{
MARKET FORCES, STRATEGIC MANAGEMENT, HRM PRACTICES AND ORGANIZATIONAL PERFORMANCE, A MODEL BASED IN A EUROPEAN SAMPLE
}

\author{
RITA CAMPOS E CUNHA \\ Faculdade de Economia \\ Universidade Nova de Lisboa \\ Rua Marquês de Fronteira, 20 \\ 1099-038 Lisboa \\ Portugal \\ rcunha@fe.unl.pt
MIGUEL PINA E CUNHA
Faculdade de Economia
Universidade Nova de Lisboa
Rua Marquês de Fronteira, 20
1099-038 Lisboa
Portugal
mpc@fe.unl.pt

\author{
ANTÓNIO MORGADO \\ Faculdade de Economia \\ Universidade Nova de Lisboa \\ Travessa Estevão Pinto \\ 1099-032 Lisboa \\ Portugal \\ antjm@fe.unl.pt
}

\section{CHRIS BREWSTER}

South Bank Business School

South Bank University, London

103 Borough Road,

London SE1 0AA

UK

chris.brewster@sbu.ac.uk

\footnotetext{
The authors thank Maria Rosário O. Martins and Alexandra Machaz for their helpful suggestions. The article benefited from the thoughtful and pertinent feedback of the anonymous JMR reviewers, which the authors acknowledge gratefully.
} 


\title{
MARKET FORCES, STRATEGIC MANAGEMENT, HRM PRACTICES AND ORGANIZATIONAL PERFORMANCE, A MODEL BASED IN A EUROPEAN SAMPLE
}

\begin{abstract}
This study uses structural equation modeling to test a model of the impact of human resources management practices on perceived organizational performance, on a large sample of European companies. The influences of competitive intensity, industry attractiveness and strategic management are considered in the model, and their direct and indirect influence on organizational performance is assessed. The model produced an adequate fit and results show that strategic management does influence human resource practices. Human resource flexibility practices and performance management have a positive impact on organizational performance, while training was not found to have a significant impact. A direct positive impact of competitive intensity and industry attractiveness on strategic management was supported by the data, as well as a direct positive effect of industry attractiveness on perceived organizational performance.
\end{abstract}


One of the central topics of discussion in management and organization theory in recent years has been change in business landscapes (e.g. Bettis \& Hitt, 1995; Parks \& Kidder, 1994). These changes have been assumed to be forcing organizations to adapt their practices in order to remain competitive. These adaptive efforts may be due, to a great extent, to the rapid diffusion of new technologies that created conditions for the socalled knowledge revolution (Hitt, Ireland \& Lee, 2000), which brought human resource management practices to a new prominence. As Kanter (1986) states, the new workforce is meeting a changing workplace. The management of human resources is one of the ways companies may use to increase their competitiveness in the new organizational landscapes, since managing in a global marketplace, introducing new technology, developing organizational knowledge, improving customer service or product quality or reducing product/service costs, requires considering the "human equation" (Pfeffer, 1998a).

A significant body of previous research has reported positive associations between human resource management (HRM) systems and organizational performance. These studies focus on the impact of several specific HRM practices, such as compensation (Gerhart \& Trevor, 1996; Gomez-Mejia, 1992), training (Bartel, 1994) or performance management systems (McDonald \& Smith, 1995). Other studies report the positive impact of progressive HRM practices on organizational performance (Delaney \& Huselid, 1996; Huselid, 1995) as well as the virtuous impact of HR sophistication, measured by investments in HR planning, in hiring and in employee development on labor productivity, particularly in capital intensive organizations (Koch \& McGrath, 1996). 
How these various HRM practices are jointly affected by external and internal environmental variables and how they affect organizational results is a comparatively understudied topic (e.g. Jackson \& Schuler, 1995). This study addresses this gap by testing a model that offers a comprehensive framework. We integrate exogenous market forces and endogenous strategic management characteristics and HRM practices, and examine how these factors influence perceived organizational performance.

A major contribution of this study is that it explicitly considers direct and indirect influences on organizational performance, in an integrated model. We do so by applying structural equation modeling to a large sample of European companies in 11 different countries.

\section{BACKGROUND AND HYPOTHESES}

Companies have been advised to develop mission statements and elaborate strategy definitions, which provide direction, goals and profitability targets for their activities (e.g. Chandler, 1962; Mintzberg, 1973; Porter, 1980). They should also create specific functional strategies, such as financial management or marketing strategies, which define how the companies will allocate their resources in order to achieve their mission and goals. The exercise of strategic planning helps managers to analyze the relevant environmental and internal conditions, in order to anticipate opportunities and threats and therefore improve organizational performance. According to this logical incrementalism perspective (Quinn, 1978), the top management teams set the corporate strategy and sub-units develop specific strategies and tactics needed to respond effectively to environmental challenges (Wright, McMahan \& McWilliams, 1994).

The implementation of corporate and functional strategies depends on the companies' resources and, particularly, on people. The human resource strategy focuses on how the 
company should manage its staff to assist the organization in the achievement of corporate objectives (Walker, 1992, Schuler \& Jackson, 1987). As such, it is argued that companies with explicit mission statements and corporate strategies could be expected to have developed aligned human resource strategies to address the issues relevant for strategy implementation (Schuler \& Jackson, 1987). Thus, the strategy pursued by the company is correlated with the needs of human resources, the skills that must be acquired, or that are already possessed, and the types of control systems to ensure the achievement of business goals. According to the resource-based view of the firm, strategies are contingent on having the human resources needed for their implementation (Wright, McMahan \& McWilliams, 1994).

Positive correlations have been found between the degree of planning formality and firm performance (Lyles et al, 1993; Pearce, Robbins \& Robinson, 1987) because greater emphasis will be placed on improving the quality of the strategic decisionmaking process, such as goal formulation, developing distinctive competences, determining authority relationships, deploying resources and monitoring implementation. Tregaskis (1997) also found that organizations with a formalized HR strategy had a higher probability of adopting practices in line with high performance work systems than those with informal or no HR strategy.

These views of the strategy formulation process are somewhat at odds with the latest thinking on corporate strategy, which argues that in practice strategies are incremental, emergent and messy (Johnson \& Scholes, 1988; Mintzberg \& Waters, 1982). However, the counter-argument is that the "commander" model (Bourgeois \& Brodwin, 1984) does have value: strategic clarity, which derives from a clearly defined mission and corporate strategy, plus a matching HR strategy, may be expected to positively influence organizational performance through HR practices. In our model, strategic 
management is measured by the existence of a mission, corporate strategy and HR strategy, as well as by the degree of formalization of these factors. We also consider that strategic management will act as a trigger to the implementation of more progressive HR practices and that these practices will impact organizational performance.

As Delaney and Huselid (1996) point out, HRM practices affect organizational performance through their impact on employees' skills and ability, motivation and work organization. In this study we also focus on HRM practices in these three areas, by considering training, performance management and HR flexibility respectively, and analyzing how they are associated with strategic management issues.

To improve employees' skills and abilities and, thus, increase the quality of the existing workforce, companies with formalized strategic management practices will emphasize and invest in employee training and development activities, in line with the business strategy (Arthur, 1994; Huselid, 1995, Jackson \& Schuler, 1995). In the same vein, Tregaskis (1997) found out that organizations with formalized strategies were more likely to invest in training and development activities. Investments in the development of firm-specific skills have been found to be associated with productivity pay-offs and a degree of inimitability that competitors cannot duplicate (Koch \& McGrath, 1996), stressing the importance of internal fit for achieving sustainable competitive advantage. Our first hypothesis, therefore, will be:

H1: Strategic management positively affects the amount of training provided by companies.

Research studies have demonstrated that training has a positive influence on organizational performance. Bartel (1994) for example, has demonstrated that investments in training programs made by low productivity companies resulted in 
productivity growth large enough to reach the labor productivity levels of comparable businesses. Russell, Terborg and Powers (1985) have shown a strong positive relation between percentage of trained employees and performance. In their study of retail stores, the percentage of trained employees had a significant positive relation with two measures of store performance: volume per employee and store image. Pfeffer (1998a) also considers training to be one of the characteristic dimensions of organizations that produce profits through people, not only because it is a way of developing skills but also because of the positive attitude it elicits in individual employees, of being part of the company, "playing in the game" (Pfeffer, 1998b, p.116). We should therefore expect that financial investment in training activities as well as amount of training received is positively associated with organizational performance. Hence:

H2: Training positively affects organizational performance.

Strategic planning should also be related to motivation and performance management programs, the second factor to which Delaney and Huselid (1996) attribute an impact on organizational performance. Performance management, which is composed of two closely related components (appraisal and pay) is intended to improve organizational performance by motivating employees to achieve objectives that are critical to the organization's strategic direction (Marshall, 1998).

Several motivation theories stress the contribution of performance pay for work motivation (e.g., Adams, 1963; Porter \& Lawler, 1968). Additionally, research has shown that compensation strategies include at least two options: fixed pay and variable pay, and that the relative weights of these two components are aligned with corporate strategy (Gomez-Mejia \& Balkin, 1992). For example, organizations facing high 
degrees of turbulence need to be more financially flexible (Stroh et al, 1996; Thompson, 1967) shifting the risk to the workforce in the form of variable pay.

However, for performance pay schemes to operate effectively, there should be a link between employee performance and subsequent reward, as well as a perception of equity in reward distribution (Lawler, 1990; Milkovich \& Wigdor, 1991). Appraisal provides the means by which organizations can assess the contribution of employees, provide feedback on current performance and motivate staff to reach higher standards of performance (Marshall, 1998). Performance appraisal systems, on the other hand, define what is meant by implementation and adherence to the strategic plan at the level of an individual employee (Becker, 1988; Latham, 1984; Murphy \& Cleveland, 1991). They then become organizational mechanisms for strategy communication (Beck, 1987; Reed \& Buckley, 1988). Hence:

H3: Strategic management positively affects performance management practices, through use of performance pay systems and of performance appraisal systems.

Empirical research has demonstrated positive links between incentive compensation and organizational performance, through productivity increases (Gerhart \& Milkovich, 1992; Gupta \& Shaw, 1998), lower employment variability (Gerhart \& Trevor, 1996) and the reinforcement of corporate strategy (Gomez-Mejia, 1992). It is this kind of research that suggests that there seems to be an "increasing link being forged between pay and performance" among both American and European organizations (Sparrow \& Hiltrop, 1994, p.46).

Similarly, the use of more valid and accurate performance appraisal systems can also contribute to employee motivation, through feedback, the identification of training and development needs, and goal setting practices. Multi-source feedback, or $360^{\circ}$ feedback, 
has gained increased popularity in the literature, precisely because of the value of the feedback employees may receive from sources not covered in more traditional performance appraisal systems (London \& Smither, 1995).

Considering that accurate feedback and contingent rewards are the essence of performance management (Marshall, 1998), and that these must be closely aligned with corporate strategy, it has been shown that this combination has a significant impact on the organizational financial and productivity measures (McDonald \& Smith, 1995). Pay for performance and accurate feedback (particularly of the $360^{\circ}$ type) constitute a powerful tool for managing organizational performance.

From these arguments, we derive our next hypothesis:

H4: Performance management systems positively affect organizational performance.

Due to changing market opportunities and technology, as well as increasing international competition, firms experience greater uncertainty and are, therefore, motivated to cost reduction. Given that labor costs are, for most organizations, the largest single element of operating costs, there is a strong relationship between strategic management and the use of contingent employment. Evidence has been presented that high users of part-time workers are more likely to have written corporate strategies and written HR strategies, their use being the result of strategic decision-making (Mayne, Tregaskis \& Brewster, 1996). Companies with formal strategic planning processes will most likely, more carefully consider this strategic alternative. The reliance on an increasingly contingent staff, made up of temporary and part-time workers, has also been depicted as a way to reduce benefits costs, to screen potential workers for regular full-time positions or even to adjust staffing levels to cope with fluctuations in companies' workload or fluctuations in demand, while avoiding the morale problems 
caused by layoffs (Pfeffer, 1994). Contingent employment practices take many forms and are likely to have differential effects (Brewster \& Tregaskis, forthcoming). In this study we have chosen to focus on the most common form in Europe, part-time employment. In the European Union, the average percentage of the workforce in parttime jobs has increased from 14.3 in 1992 to 16 percent in 1995 (Clifford, Morley \& Gunnigle, 1997). Houseman (2001) concluded that the main reasons for using part-time workers in the U.S. is that this type of HR flexibility had to do with accommodation of employee's desires for short hours and the need to accommodate workload fluctuations. On the other hand, results from her study of 550 American private sector companies from several industries and sizes, led her to suggest that in order to deal with workload fluctuations, "the lower benefits costs made such arrangements more attractive as an option" (Houseman, 2001, p.168).

From this, we derive our hypothesis:

H5: Strategic management positively affects HR flexibility practices.

Although it has been argued that some contingent working practices may have dysfunctional effects, such as temporary and fixed term contracts (Kelley, 1995; Medcoff \& Needham, 1998; Pfeffer, 1994; Turnley \& Feldman, 1999) this may not apply to practices such as part-time contracts, which may benefit both employers and employees, by making it more likely that employees are only paid for actual hours worked and adjusting to particular needs of the workforce (namely women) who want less working hours and more flexible work schedules (Nayar \& Willinger, 2001; Papalexandris \& Kramar, 1997). Increasing female participation in the labor force and the need to balance work and family life has been used as explanation to the higher proportion of part-time employees (Brewster, Hegewisch \& Mayne, 1994). On the other 
hand, part-time contracts increase working time flexibility, to cover for longer opening hours or weekend working (Sparrow \& Hiltrop, 1994), contribute to cost reduction for employers (Anon, 1994) and may result in productivity increases (Anonymous, International Labour Review, 1995).

Considering the positive effects for employers and employees, our next hypothesis will then be:

H6: HR flexibility practices will positively impact organizational performance.

Finally, we consider two constructs associated with organizational environment: competitive intensity and industry attractiveness. ${ }^{1}$ These two constructs are qualitatively different and correspond to what Milliken (1987), for example, has referred to as state of the environment and effects of the environment, respectively.

State of the environment comprises key organizational constituencies, such as suppliers, competitors, consumers, government, shareholders, etc., which may affect organizational strategic planning and are associated to a certain type of uncertainty. Effects of the environment concern the impact of a given set of conditions of the environment on the organizational ability to function in that future state. Competitive intensity is characteristic of the state of the environment, while product/service demand and market growth are effects of the environment. These two types of external factors are expected to indirectly influence organizational performance, through the process of strategic management and HRM practices (Schuler \& Grover, 1996).

Competitive intensity, or the degree of competition that a firm faces, affects organizational focus and attention on competitors (Grewal \& Tansuhaj, 2001) and leads top management into spending a greater amount of time and resources on environmental

\footnotetext{
${ }^{1}$ We particularly thank for the insightful comments made by the two anonymous reviewers, in a previous version of this article, regarding organizational environment and industry characteristics.
} 
scanning and forecasting (Milliken, 1987). Enlargement or even introduction of product market competition has been one of the purposes of major privatization programs around the world because it will force organizations to develop better competitive strategies and pay closer attention to costs (Ramaswany, 2001). Evidence has also been presented that increased competition enhances productivity, by making better use of available resources and selecting out less fitted competitors (Hannan \& Freeman, 1989; Pavcnik, 2002) and by increasing innovation (Blundell, Griffith \& Van Reenen, 1999). Hence, our next hypothesis:

H7: Competitive intensity will positively affect strategic management.

Although several factors have been associated with industry attractiveness, by different authors, we use two indicators, product/service demand and market growth, which are consistently included in this construct.

Industry attractiveness is supposed to affect organizational performance by forcing companies to perform more effective environmental scanning (Grewal \& Tansuhaj, 2001), to define appropriate corporate strategies, with a better internal fit among functional policies (Porter, 1996) and to spend more managerial time "in the environmental threat and opportunity analysis phase of strategic planning" (Milliken, 1987, p.140). Industry attractiveness is also likely to affect organizational performance, namely due to higher environmental munificence (Pfeffer \& Salancik, 1978). Environmental munificence is positively associated with strategic options available to firms, but in the same industry, an environmental condition can present an opportunity for some organizations and a threat to others, depending on their strategic goals, strengths and weaknesses (Castrogiovanni, 1991), which means that attractiveness has a differential impact, depending on the firm's relative advantages. According to 
Wernerfelt and Montgomery (1986) the amount by which efficient firms outperform inefficient ones is smaller when there are more inefficient firms and if industry prices are less volume sensitive, two conditions that are associated with high industry growth. These authors have shown that efficient diversifiers do better in more profitable industries while inefficient diversifiers benefit from high market growth. In addition, Luo (1998) found out that both firm competence and industry attractiveness attributes contribute and are critical to high organizational performance, although industry structural attributes have a somewhat stronger influence. It may be expected, therefore, that a decrease in demand for a product or service or a decline in market growth will have a direct negative impact on organizational performance, although strategic competencies will play a major role in the way firms react and cope with these attributes.

From these arguments, we may consider that industry attractiveness may have an indirect impact on organizational performance, through the strategic management process, but also a direct effect, due to environmental threat reduction. Hence, our last hypotheses:

H8: Industry attractiveness will positively affect strategic management. H9: Industry attractiveness will positively affect organizational performance.

The model presented in Figure 1 was built considering the hypotheses derived from the literature review presented above.

INSERT FIGURE 1 HERE 
According to this model, two exogenous variables - competitive intensity and industry attractiveness - are expected to have an indirect positive impact on organizational performance, through the development of a strategic management emphasis. Industry attractiveness is also expected to have a direct positive impact on organizational performance. Strategic management, in turn, is expected to influence performance through its impact on the development of matching HR practices, in such areas as training, performance management and HR flexibility. These HRM practices are hypothesized to have a direct positive impact on organizational performance. In the following section, we discuss how we have tested the model.

\section{METHOD}

\section{Sample}

For this study, we used the 1995/96 survey on strategic HRM, developed by the CRANET-E Network. This survey provides comprehensive organizational information on the strategic human resource management of companies in a number of European countries. The same data collection instrument has been used in all countries, after translation and back translation in the participating countries by a local team. In each organization, the instrument was completed by the senior HR manager. The survey is organized around six sections covering the personnel/human resource function, staffing, employee development, compensation and benefits, employee relations and communications, and organizational details (for further information see Brewster et al, 2000).

A total of 6,289 questionnaires were returned from 29,540 distributed in the countries involved. This makes it perhaps the largest survey of HRM policies and practices ever 
conducted in Europe. The response rate was 21\%: high for a full-population, postal survey. There was, as in past years, some variation in response rates across countries, ranging from over $50 \%$ in Sweden to just over $10 \%$ in some of the Southern European countries. This may in part be due to differences in attitudes towards surveys and the willingness for the disclosure of organizational details across countries. Academic partners in each country were responsible for checking the data against other information, but reliable comprehensive databases of organization are not available. Using employment numbers as a proxy it would seem that, across Europe, the responses over-represented manufacturing and larger firms. It was not possible to check respondents/non-respondents, although first-ten-percent/last-ten-percent comparisons showed no significant differences. Europe has substantial proportions of public sector and small and medium sized enterprises, which were not relevant to our hypotheses. Restricting the sample to private sector companies with more than 200 employees, reduced the total numbers to 1,806 firms. Since this is a large sample, we deleted all cases with missing data on any of the measures, as well as the cases pertaining to countries with a sample size up to 15 . The final sample has 1,301 organizations. The average size, by number of employees, is 1,690, ranging from 200 to 174,400 , with a median of 440. Tables 1 and 2 present the distribution of companies by country and industrial sector.

INSERT TABLE 1 HERE

INSERT TABLE 2 HERE 


\section{THE MODEL}

The hypotheses presented above were analyzed with structural equation modeling (SEM). We should not lose track of the fact that though we single out some variables as causes and others as effects, no statistical method is capable, by itself, of establishing a "cause" and an "effect" (Dillon \& Goldstein, 1984). Cause and effect are of course theoretically driven. The model presented in Figure 1 was built considering the hypotheses derived from the literature review presented above.

\section{Measures}

The overall measurement model employs 18 measures for the 7 constructs. Two of the constructs are exogenous factors that represent market characteristics - competitive intensity $\left(\xi_{1}\right)$ and industry attractiveness $\left(\xi_{2}\right)$. The other five are endogenous factors strategic management $\left(\eta_{1}\right)$, training $\left(\eta_{2}\right)$, performance management $\left(\eta_{3}\right)$, HR flexibility $\left(\eta_{4}\right)$ and organizational performance $\left(\eta_{5}\right)$.

Competitive intensity was measured by one question, concerning change in the level of competition over the last 3 years, on a 3-point scale (1-decreased; 2-same; 3-increased). Industry attractiveness was measured by two questions, on a 3-point scale, concerning change in demand for product/service over the last 3 years (1-decreased; 2-same; 3increased) and change in market growth (1-declining; 2-same; 3-growing).

Strategic management was measured by three questions regarding the existence of a mission statement, a corporate strategy and a personnel/HRM strategy, on a 1 to 3 scale (1-no; 2-yes, unwritten and 3-yes, written). Each of these three variables was transformed into two dummy variables: existence (0-No; 1 -Yes) and formalization ( 0 unwritten; 1-written). In order to estimate the model, we had to add the three dummy 
variables pertaining to existence, to produce one indicator of the existence of strategy, ranging from 0 (no mission, no corporate strategy, no HR strategy) to 3 (existence of mission, corporate strategy and HR strategy). We also added the three dummy variables pertaining to formalization, to produce one indicator of strategy formalization, ranging from 0 (unwritten mission, corporate strategy and HRM strategy) to 3 (written mission, corporate strategy and HRM strategy).

To estimate the model, the latent variable strategic management is therefore measured by two indicators: strategy existence and strategy formalization.

Training was measured by five indicators: a continuous variable representing the proportion of annual salaries and wage bills spent on training, and four continuous variables representing the average number of days of training for managers, for technical/professional staff, for clerical employees and for manual employees. All these five measures report to the year before the survey, and were standardized for the estimation of the model.

Performance management was assessed by five indicators: the use of multi-source feedback, by counting the number of participants in the performance appraisal procedure (immediate superior, next level superior, the employee, subordinates, peers, customers and others), ranging from 0 to 7 . From the whole sample, 234 companies did not have a performance appraisal system for any of the work categories (managers, technical/professional, clerical and manual).

The other four manifest variables indicate how many types of different incentives the company gave to managers, technical/professional employees, clerical employees and manual employees. Five types of incentives were mentioned in the questionnaire, for respondents to check all applicable: employee share options, profit sharing, group bonus, individual commission and merit pay. We therefore have four variables, ranging 
from 0 to 5 . In the whole sample, only 149 companies did not have any kind of incentives for any of the four work categories. The five indicators for the latent variable performance management were also standardized, for the estimation of the model.

HR flexibility was measured by two questions: change in the use of part-time contracts, on a 3 point scale (1-decreased; 2- same and 3-increased) and approximate proportion of the workforce on part-time contracts, on a 5 point scale $(1-<1 \% ; 2-1-5 \%$; $3-6-10 \%$; 4 $11-20 \%$ and $5->20 \%$ ). These two indicators were standardized for the estimation of the model.

Organizational performance was measured by one question asking the respondent to report the company's perceived gross revenue over the past three years, on a 5-point scale (1-so low as to produce large losses; 2-insufficient to cover costs; 3-enough to break even; 4-sufficent to make a small profit and 5-well in excess of costs).

The choice of a subjective measure of organizational performance is based on the fact that in international surveys, objective performance measures are dangerous, because of cultural differences between national long-term and short-term orientations, and differing tax and fiscal regimes, which may bias the financial statements and make them non-comparable (Lahteenmaki \& Vanhala, 1998; Martell \& Carroll, 1995; Verhage \& Waarts, 1988). A strong correlation between subjective responses and objective measures of performance has also been found (Pearce, Robbins \& Robinson, 1987). In the circumstances, a perception of the financial success of the organization may be at least as effective as any "objective" profit rating or ROI measures.

In Table 3, we present the reliability coefficients (Cronbach's alpha) for the constructs. All variables in the model are at acceptable levels of reliability, although HR flexibility and industry attractiveness are marginally below the 0.7 cutoff (Nunnally, 1967, p.226, 
considers a range of 0.5 to 0.6 to be acceptable for preliminary research; Murphy \& Davidshofer, 1988, p.89, considers 0.6 to be the cutoff for an unacceptable level).

\section{INSERT TABLE 3 HERE}

\section{Analysis}

We tested the measurement and structural models using AMOS 4.0 (Arbuckle \& Wothke, 1999) to generate maximum likelihood parameter estimates through the analysis of the matrix of covariance among variable scores. We assessed model fit using the Goodness of Fit (GFI) and Adjusted Goodness of Fit (AGFI) Indices, the Tucker Lewis Index (TLI) and the Root Mean Square Error of Approximation (RMSEA). These last two indices include parsimony as a criterion in the estimation of fit (i.e., impose a penalty for inclusion of additional paths). GFI, AGFI and TLI values greater than 0.90 are generally considered to indicate a good fit. Values of RMSEA below 0.08 indicate a reasonable fit, and those below 0.05 indicate good fit to the data (Browne \& Cudeck, 1993).

\section{Results}

All non-fixed indicator loadings for each construct are significant at $1 \%$ level, as reported in Table 4. We corrected for measurement error in the two single-item latent variables - competitive intensity and organizational performance - by specifying an arbitrary value of 0.70 as reliability of these two variables. Error variances were set equal to the observed variables' variances times 1 minus the established reliability (Jöreskog \& Sörbom, 1993; Schumacker \& Lomax, 1996). 
The means, standard errors and correlations among the manifest variables are reported in Table 5. In the diagonal, we report the squared multiple correlations for each of the manifest variables. Strategy existence and formalization are significantly correlated with the training, performance management and part-time working indicators, and indicators for the latent variables are also significantly inter-correlated. With the exception of the competitive intensity, training indicators and change in use of part-time contracts, all manifest variables are also significantly correlated with perceived gross revenue, the indicator for the latent organizational performance.

INSERT TABLE 5 HERE

The estimated model exhibits a highly satisfactory fit: GFI $=0.93$; AGFI $=0.91$; $\mathrm{TLI}=0.90$; RMSEA $=0.06$. The model can thus be considered valid in general terms, although one of the paths hypothesized in our model was not supported by the estimated parameters. The path coefficients obtained in the estimation of the model are reported in Fig. 2 and Table 6.

INSERT FIG.2 HERE

INSERT TABLE 6 HERE 
In particular, strategic management has positive impacts on training $\left(\mathrm{H}_{1}\right)$, significant at $\mathrm{p}<0.01$, performance management $\left(\mathrm{H}_{3}\right)$, significant at $\mathrm{p}<0.01$, as well as on $\mathrm{HR}$ flexibility $\left(\mathrm{H}_{5}\right)$, significant at $\mathrm{p}<0.01$.

Performance management also has a significantly positive $(\mathrm{p}<0.01)$ impact on organizational performance, according to our hypothesis $\left(\mathrm{H}_{4}\right)$. HR flexibility too has a significant positive impact $(\mathrm{p}<0.01)$ on organizational performance $\left(\mathrm{H}_{6}\right)$.

In support of hypothesis $\left(\mathrm{H}_{7}\right)$, the path coefficient deriving from competitive intensity to strategic management is statistically significant at 0.01 level, as well as the path linking industry attractiveness and strategic management $\left(\mathrm{H}_{8}\right)$. Hypothesis $\left(\mathrm{H}_{9}\right)$, which assumed a positive direct impact of industry attractiveness on organizational performance, was confirmed by the data $(\mathrm{p}<0.01)$.

Only $\left(\mathrm{H}_{2}\right)$, which proposed a positive effect of training on organizational performance, was not supported in the model $(\mathrm{p}<0.66)$. This was an unexpected result, which we will try to interpret in the next section.

\section{DISCUSSION AND CONCLUSIONS}

This paper reports on our attempt to draw a model of how environmental factors, strategic management and HRM practices combine to influence organizational performance, using a European sample. The model illustrates the role played by market characteristics, namely competitive intensity and industry attractiveness. The characteristics of the market do in fact show a direct influence over several of the endogenous variables in our model. For example, the level of competition experienced by a firm is related to the degree to which organizations attempt to define and formalize 
mission statements, corporate strategies and HRM policies. This is consistent with previous research (Blundell, Griffith \& Van Reenen, 1999; Grewal \& Tansuhaj, 2001; Pavcnik, 2002; Stimpert \& Duhaime, 1997) arguing that firms have to focus on what competitors are doing and on the ways to improve organizational effectiveness and efficiency, by cutting costs, innovating, creating market share and improving customer satisfaction. In the same vein, industry attractiveness affects strategic management, which is consistent with Luo (1998), who stressed that the match between firm competence and industrial conditions is essential to achieve benefits from international investment. Our results also support a direct positive effect of industry attractiveness on organizational performance, a similar result to that obtained by Luo (1998), suggesting that industry structural attributes have a stronger effect on performance than firm competence variables.

Thus, and not surprisingly, market dynamism can be thought of as a powerful influence on the functioning of organizations, with more attractive and competitive markets leading to attempts to introduce higher levels of systematization (e.g. strategic clarity) and to enhanced effectiveness (i.e. performance) in management practices. The importance of environmental scanning for the characteristics of competitors and for environmental threats and opportunities is one of the implications of this study. Managers must consider and respond to these challenges by defining unique corporate strategies. Future research should focus on how strategic planning is affected by different environmental characteristics, including factors not included in this study, such as the institutional context. European surveys may prove to be useful for that purpose, since even within the European Union, different institutional backgrounds are present, regarding labor markets, fiscal policies, educational and legal systems, for example. 
Secondly, our results also illustrate the important role of strategic management as a determinant of HRM practices. The existence of strategic thinking and strategic formalization impacts the adoption of part-time work contracts and performance management, as well as the amount of training provided. This can be interpreted as meaning that companies that invest more in defining precisely what goals to pursue may be more willing and able to rigorously define what performance they want to obtain and how it should be measured, as well as how performance-enhancing behaviors should be identified and rewarded. These companies will also be more willing to invest in the development of required employee skills and knowledge, through the provision of training programs that are aligned with strategic objectives and to consider contractual options that are advantageous for both firm and workers. The strategic role of HRM is emphasized by these results. The involvement of the HR function at the strategic/board level may guarantee the needed unique configuration of corporate strategy and matching HRM, which will contribute to sustained competitive advantage. On the other hand, there is room for future research on how strategic is HRM in different competitive situations and how valuable is the internal fit between corporate strategy and HRM for organizational performance, namely taking organizational culture in consideration.

A third set of results pertains to the direct impact of HRM practices on organizational performance. Performance management showed a positive and significant impact on organizational performance, as expected and consistent with previous literature (e.g., Gomez-Mejia, 1992; Gupta \& Shaw, 1998; McDonald \& Smith, 1995). Part-time working also has a significant positive impact on organizational performance, as hypothesized. Organizations, which can make more cost-effective use of their labor, whilst meeting employee needs, are more likely to be successful. 
Much to our surprise, training did not have a significant impact on organizational performance, which deserves a special analysis and discussion. Several explanations may contribute to this result. Firstly, training results are usually visible in the long-run, and at the same time, organizational knowledge can be considered as a "stock", while we were measuring "flows" (e.g. Narasimha, 2000). Another possible explanation concerns training design. Effective training should be based on analyzing people's needs, turning explicit "what people must start doing, stop doing and continue to do to execute strategy" (Latham, 2001, p.4). Training must not only be evaluated, but also aligned with corporate strategy and the other HR practices, such as performance appraisal and compensation. Our data did not capture this internal fit. Thirdly, while Bartel (1994) found significant increases in productivity due to implementation of training programs, over a period of 3 years, Koch and McGrath (1996) failed to find support for their hypothesis that training would lead to productivity increases. In this study, training was measured by financial investment in training activities and also by average number of training days in one year, which is common in this kind of research. So, the lack of impact of training may also derive from our measurement of the construct. Maybe a more appropriate way would be to measure training through multiannual investments, as well as types of training programs implemented and their impacts. The theoretical arguments behind the impact of training are sufficiently strong to deserve a more detailed analysis of the issue.

This third set of results suggests that competitive advantage may be strengthened through performance management practices that enhance worker motivation as well as through flexible contracts that are valued by both workers and organizations, within a long-term perspective. In this sense, investments in the development of core 
competencies still hold a promise for organizational performance, that the data in this study did not reveal.

Taken together, these results stress the fact that companies are exposed to the effects of market characteristics and the ones that face more competition and have more attractive industry conditions, are more motivated to conduct better environmental scanning and strategic planning, becoming better equipped to adopt performance-oriented management systems through strategic HRM practices.

\section{Limitations of the study}

Our model, while focusing the impact of the external market, does not take into account the firm's strategic type (e.g., Porter, 1985), or the life-cycle stage of the organization (e.g., Hendry and Pettigrew, 1992).

There are other methodological limitations on this research imposed by the process of using survey data with single respondents (Gerhart et al, 2000). Additionally, two of the latent variables suffered from low reliability, HR flexibility $(\alpha=0,68)$ and especially industry attractiveness $(\alpha=0,64)$, which must be presented as a limitation, considering the large sample size in the study.

Another limitation probably comes in the conflation and restriction of the data to Europe. The European countries are by no means alike in their management of human resources and the techniques used here risk "averaging out" important differences. On the other hand, there are clear differences between Europe as a whole and other continents (Brewster, 2001). There have been attempts to describe a European model of HRM, which emphasizes the cultural differences, the extensive role of Government and legislation, the influence of the unions and the extent of consultation (Brewster, 1993, 1995; Sparrow \& Hiltrop, 1994; Thirley \& Wirdenius, 1989), but a comparative 
analysis was not the goal of this study. These differences in HRM between Europe and the rest of the world may mean that replications of this research elsewhere will not find exactly the same results.

It would have been interesting to compare the finding on part-time working with other, perhaps more contentious and employee-unfriendly forms of contingent working, such as short-term employment. There should also have been a variable dealing with staffing practices, which we were not able to include, due to lack of reliability of the measures in the survey. We nevertheless acknowledge the importance of recruitment and selection practices for organizational performance and will attempt to address it in future research.

\section{Conclusion}

In general, this research confirms the need to study HRM not as an internal organizational function but as an instrument of organizational adaptation. This is in line with the literature that suggests the need to understand HRM in the context of the relationship between organizations and their environments (e.g. Jackson \& Schuler, 1995). HRM practices seem to be influenced, in fact, by the way organizations perceive their environment and how they respond to environmental challenges.

This relationship between environmental textures and organizational structures and processes is far from new in the organizational debate (e.g. Lawrence \& Lorsch, 1967) and even in the HRM literature (e.g. Sisson \& Timperley, 1994). Nevertheless, the way the environment influences the practice of human resource management is far from uncovered. We dare to say that the black box is still closed and in most cases it is only studied at the theoretical or anecdotal levels. Our contribution with this paper is to explore, at a macro level, the way HRM practices and market factors interact. Based on 
a large sample of European firms, we highlighted how market characteristics and strategic factors combine to generate a stream of HRM decisions that influence organizational performance.

Our conclusions may also have relevant consequences for HRM practitioners. Apart from the aspects derived from each individual hypothesis, the study clearly suggests the need to match HRM and organizational strategies. This, again, is not new in the literature (e.g. Gomez-Mejia \& Balkin, 1990) but has been demonstrated here with a large scale, international, non-American sample. Therefore, the need to understand HRM in a strategic perspective is emphasized. Our results reinforce the advice offered by Tichy, Fombrum and Devanna (1982) twenty years ago: "effective strategic management requires effective human resource management" (p.60). Our evidence, in fact, indicates the strength of the links between the environment, organizational strategy and HRM practices, as well as the connection between strategy and HRM factors. The strategic view of HRM, therefore, seems to be here to stay. 


\section{REFERENCES}

Adams, J. (1963). "Toward an understanding of inequity", Journal of Abnormal and Social Psychology, Vol. 67: 422-436.

Anon (1994). "Planning pointers: part-time work”, Business Europe, Vol.34 (16): p.8.

Anonymous (1995). "Working time and employment: new arrangements", International Labour Review, Geneva.

Arbuckle, J. \& Wothke, W. (1999). AMOS 4.0, SmallWaters Corporation, Chicago, IL.

Arthur, J. (1994). "Effects of human resource systems on manufacturing performance and turnover", Academy of Management Journal, Vol.37 (3): 670-687.

Balkin, D.B. \& Gomez-Mejia, L.R. (1990). "Matching compensation and organizational strategies" Strategic Management Journal, Vol. 11: 153-169.

Bartel, A. (1994). "Productivity Gains from the Implementation of Employee Training Programs", Industrial Relations, Vol. 33: 411-425.

Beck, R. (1987). "Visions, values and strategies: Changing attitudes and culture", Academy of Management Executive, Vol.1 (1), 33-41.

Becker, C. (1988). Performance evaluation: An essential management tool, ICMA, Washington, DC.

Bettis, R. \& Hitt, M. (1995). “The new competitive landscape”. Strategic Management Journal, Vol. 16: 7-19.

Blundell, R., Griffith, R. \& Van Reenen, J. (1999). "Market share, market value and innovation in a panel of British manufacturing firms", Review of Economic Studies, Vol.66, 529-554.

Bourgeois, L. \& Brodwin, D. (1984). "Strategic implementation: five approaches to an elusive phenomenon" Strategic Management Journal, Vol.5 (3): 241-264

Brewster, C. \& Tregaskis, O. (2002). “Convergence or Divergence of Contingent Employment Practices? Evidence of The Role of MNCs in Europe" in W. Cooke 
(Ed.), Multinational Companies \& Transnational Workplace Issues (forthcoming)

Brewster, C. (1993). “Developing a 'European' model of human resource management", International Journal of Human Resource Management, Vol. 4, (4): $765-784$.

Brewster, C. (1995). “Towards a 'European’ Model of Human Resource Management”, Journal of International Business Studies, Vol. 26 (1): 1-21.

Brewster, C. (2001). "HRM: the comparative dimension" in J. Storey (Ed.), Human Resource Management: a critical text (second edition) Thomson Learning, London (pp.255-271)

Brewster, C., Hegewisch, A. \& Mayne, L. (1994). "Flexible working practices: the controversy and the evidence", in C. Brewster and A. Hegewisch (Eds.), Policy and Practice in European Human Resource Management. The Price Waterhouse Cranfield Study, Routledge, London.

Brewster, C., Tregaskis O., Hegewisch, A. \& Mayne, L. (2000). “Comparative Research in Human Resource Management: a Review and an Example” in C. Brewster, W. Mayrhofer and M. Morley (Eds.), New Challenges for European Human Resource Management, Macmillan, London

Browne, M. \& Cudeck, R. (1993). "Alternative ways of assessing model fit", in K.A.Bollen \& J.S. Long (Eds.), Testing structural equation models, SAGE, Newbury Park, CA.

Castrogiovanni, G. (1991). "Environmental munificence: a theoretical assessment", Academy of Management Review, Vol. 16 (3): 542-565.

Chandler, A. (1962) Strategy and Structure, MIT Press, Cambridge, MA. 
Clifford, N., Morley, M. \& Gunnigle, P. (1997). "Part-time in Europe", Employee Relations, Vol. 19 (6): 555-567.

Delaney, J. \& Huselid, M. (1996). “The Impact of Human Resource Management Practices on Perceptions of Organizational Performance", Academy of Management Journal, Vol. 39 (4): 949-969.

Dillon, W. \& Goldstein, M. (1984) Multivariate Analysis, Methods \& Applications, Wiley Series in Probability, John Wiley and Sons, New York.

Gerhart, B. \& Milkovich, G. (1992). "Employee Compensation: Research and Practice”, in M.D. Dunnette \& L.M. Hough (Eds.), Handbook of Industrial and Organizational Psychology, Vol. 3: 481-569, Consulting Psychologists Press, Palo Alto, CA.

Gerhart, B. \& Trevor, C. (1996). "Employment Variability under different Managerial Compensation Systems", Academy of Management Journal, Vol. 39 (6): 16921712.

Gerhart, B., Wright, P., McMahan, G. \& Snell, S. (2000). "Measurement error in research on human resources and firm performance: how much error is there and how does it influence effect size estimates?", Personnel Psychology, Vol. 53: 803-833.

Gomez-Mejia, L. \& Balkin, D. (1992). Compensation, organizational strategy and firm performance, South-Western, Cincinnati.

Gomez-Mejia, L. (1992). "Structure and Process of Diversification, Compensation Strategy, and Firm Performance", Strategic Management Journal, Vol. 13 (5): 381-397. 
Grewal, R. \& Tansuhaj, P. (2001). "Building organizational capabilities for managing economic crisis: The role of market orientation and strategic flexibility", Journal of Marketing, Vol. 65 (2): 67-80.

Gupta, N. \& Shaw, J. (1998). "Let the evidence speak: financial incentives are effective!" Compensation and Benefits Review, Vol.30 (2): 26-32.

Hannan, M. T. \& Freeman, J. (1989). Organizational Ecology, Harvard University Press, Boston, MA.

Hendry, C. \& Pettigrew, A. (1992). "Patterns of Strategic Change in the Development of Human Resource Management”, British Journal of Management, Vol. 3: 137156.

Hitt, M. A., Ireland, R. D. \& Lee, H. (2000). “Technological learning, knowledge management, firm growth and performance: An introductory essay", Journal of Engineering and Technology Management, Vol. 17: 231-246.

Houseman, S. (2001). "Why employers use flexible staffing arrangements: evidence from an establishment survey", Industrial and Labor Relations Review, Vol. 55 (1): 149-170.

Huselid, M. (1995). “The Impact of Human Resource Management Practices on Turnover, Productivity and Corporate Financial Performance”, Academy of Management Journal, Vol. 38: 635-670.

Jackson, S. \& Schuler, R. (1995). "Understanding human resource management in the context of organizations and their environments", Annual Review of Psychology, Vol. 46: 237-264.

Johnson, G \& Scholes, K (1988). Exploring Corporate Strategy, Prentice Hall, Hemel Hempstead. 
Jöreskog, K. \& Sörbom, D. (1993). LISREL8: Structural equation modeling with the SIMPLIS command language, Lawrence Erlbaum Associates, Hillsdale, NJ.

Kanter, R. M. (1986). "The new workforce meets the changing workplace: Strains, dilemmas, and contradictions in attempts to implement participative and entrepreneurial management”, Human Resource Management, Vol. 25 (4): 515537.

Kelley, B. (1995). “Outsourcing marches on”, Journal of Business Strategy, JulyAugust: $40-42$.

Koch, M. \& McGrath, R. (1996). "Improving labor productivity: Human Resource Management policies do matter", Strategic Management Journal, Vol.17 (5): $335-354$.

Lahteenmaki, S. \& Vanhala, S. (1998). "HRM and company performance: the use of measurement and the influence of economic cycles", Human Resource Management Journal, Vol.8 (2), 51-65.

Latham, G. (1984). “The Appraisal System as a Strategic Control”, in Fombrun, Tichy \& Devanna (Eds.), Strategic Human Resource Management, John Wiley \& Sons, New York, 87-100.

Latham, G. (2001). "A missing link in the strategic plan" in Mastering People Management, Financial Times, November 12: 4-5.

Lawler, E (1990). Strategic Pay, Jossey-Bass, San Francisco.

Lawrence, P. \& Lorsch, J. (1967). Organization and Environment. Boston, MA: Harvard Business School Press.

London, M. \& Smither, J. (1995). "Can multi-source feedback change perceptions of goal accomplishment, self-evaluations, and performance-related outcomes? 
Theory-based applications and directions for research", Personnel Psychology, Vol. 48: 803-839.

Luo, Y. (1998). "Industry attractiveness, firm competence, and international investment performance in a transitional economy", Bulletin of Economic Research, Vol. 50 (1): 73-82.

Lyles, M., Baird, I., Orris, B. \& Kuratko, D. (1993). "Formalized planning in small business: increasing strategic choices", Journal of Small Business Management, Vol. 31 (2): 38-48.

Marshall, N. (1998). "Pay-for-performance systems, experiences in Australia", Public Productivity \& Management Review, Vol. 21 (4): 403-418.

Martell, K. \& Carroll, S.J. (1995). "Which executive human resource management practices for top management are associated with higher firm performance", Human Resource Management, Vol. 34 (4): 497-512.

Mayne, L., Tregaskis, O. \& Brewster, C. (1996). "A comparative analysis of the link between flexibility and HRM strategy”, Employee Relations, Vol. 18 (3): 5-24.

McDonald, D. \& Smith, A. (1995). “A Proven Connection: Performance Management and Business Results", Compensation and Benefits Review, Jan-Feb: 59-64.

Medcoff, J. \& Needham, B. (1998). “The supra-organizational HRM system”, Business Horizons, Jan.-Feb.: 43-50.

Milkovich, G. \& Wigdor, A. (Eds.)(1991). Pay for performance: Evaluating performance appraisal and merit pay, National Academy Press, Washington, DC.

Milliken, F. (1987). "Three types of perceived uncertainty about the environment: state, effect, and response uncertainty", Academy of Management Review, Vol. 12 (1): 133-143. 
Mintzberg, H. \& Waters, J. (1982). “Tracking strategy in an entrepreneurial firm”, Academy of Management Journal, Vol. 25 (3): 465-499.

Mintzberg, H. (1973). The Nature of Managerial Work, Prentice-Hall, Englewood Cliffs, NJ.

Murphy, K. \& Cleveland, J. (1991). Performance appraisal: An organizational perspective, Allyn \& Bacon, Boston.

Murphy, K. \& Davidshofer, C. (1988). Psychological testing: Principles and Applications, Prentice-Hall, Englewood Cliffs, NJ.

Narasimha, S. (2000). “Organizational knowledge, human resource management, and sustained competitive advantage: toward a framework", Competitiveness Review, Vol. 10 (1): 123-135.

Nayar, N. \& Willinger, G. (2001). "Financial implications of the decision to increase reliance on contingent labor", Decision Sciences, Vol. 32 (4): 661-681.

Nunnally, J. (1967). Psychometric Theory, McGraw-Hill, New York.

Papalexandris, N. \& Kramar, R. (1997). "Flexible working patterns: towards reconciliation of family and work", Employee Relations, Vol. 19 (6): 581-595.

Parks, J. M. \& Kidder, D. L. (1994). "Till death do us part, changing work relationships in the 1990s", in C.L. Cooper \& D.M. Rousseau (Eds.), Trends in Organizational Behavior (Vol.1, p.111-136), John Wiley \& Sons, Chichester.

Pavcnik, N. (2002). "Trade liberalization, exit, and productivity improvements: evidence from Chilean plants", Review of Economic Studies, Vol. 69: 245-276.

Pearce, J., Robbins, D.K. \& Robinson, R.B. (1987). "The impact of grand strategy and planning formality on financial performance", Strategic Management Journal, Vol. 8 (2): 125-135. 
Pfeffer, J. \& Salancik, G. (1978). The external control of organizations, Harper \& Row, New York.

Pfeffer, J. (1994). “Competitive advantage through people”, California Management Review, Vol.36 (2): 9-28.

Pfeffer, J. (1998a). The Human Equation: Building Profits by Putting People First, Harvard Business School Press, Boston.

Pfeffer, J. (1998b). "Seven Practices of Successful Organizations", California Management Review, Vol. 40 (2): 96-124.

Porter, L. \& Lawler, E. (1968). Managerial attitudes and performance, Irwin-Dorsey, Homewood, IL.

Porter, M. (1980). Competitive Strategy: Techniques for Analyzing Industries and Competitors, Free Press, New York.

Porter, M. (1985). Competitive Advantage: Creating and Sustaining Superior Performance, The Free Press, New York.

Porter, M. (1996). “What is Strategy?”, Harvard Business Review, Vol. 74 (6): 61-75.

Quinn, J. (1978). "Strategic change: "logical incrementalism"”, Sloan Management Review, Vol.20 (1): 7-21.

Ramaswamy, K. (2001). “Organizational ownership, competitive intensity and firm performance: an empirical study of the Indian manufacturing sector", Strategic Management Journal, Vol. 22 (10): 989-998.

Reed, R. \& Buckley, M. (1988). "Strategy in action - techniques for implementing strategy", Long Range Planning, Vol. 21 (3): 67-74.

Russel, J., Terborg, J. \& Powers, M. (1985). "Organizational performances and organizational level training and support", Personnel Psychology, Vol.38 (4): 849-863. 
Schuler, R. \& Grover, R. (1996). "Market-focused management: Human resource management implications", Journal of Market-Focused Management, Vol. 1: $13-30$.

Schuler, R. \& Jackson, S. (1987). "Linking competitive strategies with human resource management practices", Academy of Management Executive, Vol. 1: 207-219.

Schumacker, R. \& Lomax, R. (1996). A beginner's guide to structural equation modeling, Lawrence Erlbaum Associates, Mahwah, NJ.

Sisson, K. \& Timperley (1994). "From manpower planning to strategic human resource management?” In K. Sisson (Ed.), Personnel Management, p.153-184. Oxford: Blackwell.

Sparrow, P. \& Hiltrop, J.M. (1994). European Human Resource Management in Transition, Prentice Hall, Hemel Hampstead.

Stimpert, J. \& Duhaime, I. (1997). "Seeing the big picture: the influence of industry, diversification, and business strategy on performance", Academy of Management Journal, Vol. 40 (3): 560-583.

Stroh, L., Brett, J., Baumann, J. \& Reilly, A. (1996). “Agency theory and variable pay compensation strategies", Academy of Management Journal, Vol. 39 (3): 751767.

Thirley, K. \& Wirdenius, H. (1989). Towards European Management, Pitman, London.

Thompson, J. (1967) Organizations in action, McGraw-Hill, New York.

Tichy, N. M., Fombrun, C. J. \& Devanna, M. A. (1982). "Strategic human resource management”, Sloan Management Review, Winter: 47-61.

Tregaskis, O. (1997). "The role of national context and HR strategy in shaping training and development practice in French and U.K. organizations", Organization Studies, Vol. 18 (5): 839-856. 
Turnley, W. \& Feldman, D. (1999). "The impact of psychological contract violations on exit, voice, loyalty and neglect", Human Relations, Vol. 52 (7): 895-922.

Verhage, B. \& Waarts, E. (1988). "Marketing planning for improved performance: a comparative analysis”, International Marketing Review, Vol. 15 (2): 20-30.

Walker, J. (1992). Human Resource Strategy, McGraw-Hill, New York.

Wernerfelt, B. \& Montgomery, C. (1986). "What is an attractive industry?" Management Science, Vol. 32 (10): 1223-1230.

Wright, P., McMahan, G. \& McWilliams, A. (1994). "Human resources and sustained competitive advantage: a resource-based perspective", International Journal of Human Resource Management, Vol. 5 (2): 301-326. 


\begin{tabular}{lcc}
\hline \multicolumn{1}{c}{ Country } & N & \% \\
\hline Belgium & 199 & 15.3 \\
Denmark & 41 & 3.2 \\
Finland & 87 & 6.7 \\
France & 187 & 14.4 \\
Germany & 54 & 4.2 \\
Ireland & 44 & 3.4 \\
Norway & 83 & 6.4 \\
Spain & 104 & 8.0 \\
Sweden & 130 & 10.0 \\
The Netherlands & 97 & 7.5 \\
United Kingdom & 275 & 21.1 \\
\hline
\end{tabular}

Table 1 - Distribution of sample by country

\begin{tabular}{lll}
\hline \multicolumn{1}{c}{$\begin{array}{c}\text { Industry } \\
\text { group }\end{array}$} & N & \% \\
\hline Services & 498 & 38 \\
Manufacturing & 803 & 62 \\
\hline
\end{tabular}

Table 2 - Distribution of sample by industry group 


\begin{tabular}{lcc}
\hline \multicolumn{1}{c}{ Latent Variables } & $\begin{array}{c}\text { \# of } \\
\text { items }\end{array}$ & $\begin{array}{c}\text { Cronbach's } \\
\text { alpha }\end{array}$ \\
\hline$\eta_{1-\text { Strategic }}$ & 2 & 0.76 \\
management & & \\
$\eta_{2}-$ Training & 5 & 0.78 \\
$\eta_{3}-$ Performance & 5 & 0.84 \\
$\begin{array}{l}\text { Management } \\
\eta_{4}-\text { HR Flexibility }\end{array}$ & 2 & 0.68 \\
$\eta_{5}-$ Organizational & 1 & \\
$\begin{array}{l}\text { Performance } \\
\xi_{1}-\text { Competitive }\end{array}$ & 1 & \\
$\begin{array}{l}\text { Intensity } \\
\xi_{2}-\text { Industry } \\
\text { Attractiveness }\end{array}$ & 2 & 0.64 \\
\hline
\end{tabular}

Table 3 - Reliability of Variables 


\begin{tabular}{|c|c|c|c|c|c|}
\hline Item & Variable & Parameter & Estimates & s.e. & $\mathbf{t}$ \\
\hline Market Growth & $\begin{array}{l}\text { Industry } \\
\text { attractiveness }\end{array}$ & 1 & & & \\
\hline Demand for product & $\begin{array}{l}\text { Industry } \\
\text { attractiveness }\end{array}$ & $\lambda_{1}$ & 1.647 & 0.257 & $6.40 * *$ \\
\hline $\begin{array}{l}\text { Competitive } \\
\text { Intensity }\end{array}$ & $\begin{array}{l}\text { Competitive } \\
\text { intensity }\end{array}$ & 1 & & & \\
\hline Strategy existence & $\begin{array}{l}\text { Strategic } \\
\text { Management }\end{array}$ & $\lambda_{2}$ & 0.668 & 0.068 & $9.81 * *$ \\
\hline $\begin{array}{l}\text { Strategy } \\
\text { formalization }\end{array}$ & $\begin{array}{l}\text { Strategic } \\
\text { Formalization }\end{array}$ & 1 & & & \\
\hline $\begin{array}{l}\text { Training days/year- } \\
\text { management } \\
\text { (Z score) }\end{array}$ & Training & $\lambda_{3}$ & 4.641 & 0.829 & $5.60 * *$ \\
\hline $\begin{array}{l}\text { Training days/year } \\
\text { technical/prof. } \\
\text { (Z score) }\end{array}$ & Training & $\lambda_{4}$ & 5.492 & 0.976 & $5.63 * *$ \\
\hline $\begin{array}{l}\text { Training days/year- } \\
\text { clerical ( } \mathrm{Z} \text { score) }\end{array}$ & Training & $\lambda_{5}$ & 4.672 & 0.834 & $5.60 * *$ \\
\hline $\begin{array}{l}\text { Training days/year- } \\
\text { manual ( } \mathrm{Z} \text { score) }\end{array}$ & Training & $\lambda_{6}$ & 4.145 & 0.744 & $5.57 * *$ \\
\hline $\begin{array}{l}\% \text { wage bill on } \\
\text { training ( } \mathrm{Z} \text { score) }\end{array}$ & Training & 1 & & & \\
\hline $\begin{array}{l}\text { Multi-source } \\
\text { feedback (Z score) }\end{array}$ & $\begin{array}{l}\text { Performance } \\
\text { Management }\end{array}$ & 1 & & & \\
\hline $\begin{array}{l}\text { Incentives managers } \\
\text { (Z score) }\end{array}$ & $\begin{array}{l}\text { Performance } \\
\text { Management }\end{array}$ & $\lambda_{7}$ & 2.297 & 0.179 & $12.84 * *$ \\
\hline $\begin{array}{l}\text { Incentives tech/prof. } \\
\text { (Z score) }\end{array}$ & $\begin{array}{l}\text { Performance } \\
\text { Management }\end{array}$ & $\lambda_{8}$ & 2.599 & 0.198 & $13.11 * *$ \\
\hline $\begin{array}{l}\text { Incentives clerical } \\
\text { (Z score) }\end{array}$ & $\begin{array}{l}\text { Performance } \\
\text { Management }\end{array}$ & $\lambda_{9}$ & 2.506 & 0.192 & $13,04 * *$ \\
\hline $\begin{array}{l}\text { Incentives manual } \\
\text { (Z score) }\end{array}$ & $\begin{array}{l}\text { Performance } \\
\text { Management }\end{array}$ & $\lambda_{10}$ & 1.829 & 0.151 & $12.14^{* *}$ \\
\hline $\begin{array}{l}\text { Proportion } \\
\text { workforce part-time } \\
\text { (Z score) }\end{array}$ & HR flexibility & $\lambda_{11}$ & 1.668 & 0.439 & $3.80 * *$ \\
\hline $\begin{array}{l}\text { Change workforce } \\
\text { part-time ( } \mathrm{Z} \text { score) }\end{array}$ & Flexibility & 1 & & & \\
\hline $\begin{array}{l}\text { Perceived Gross } \\
\text { Revenue }\end{array}$ & $\begin{array}{l}\text { Organizational } \\
\text { Performance }\end{array}$ & 1 & & & \\
\hline
\end{tabular}

$\left(^{* *}\right) p<0,01$

Table 4 - Indicator Loadings 


\begin{tabular}{|c|c|c|c|c|c|c|c|c|c|c|c|}
\hline & Variables & M & SD & 1 & 2 & 3 & 4 & 5 & 6 & 7 & 8 \\
\hline 1 & Demand for product & 2.29 & .81 & .77 & & & & & & & \\
\hline 2 & Market growth & 2.32 & .74 & $.46 * *$ & .28 & & & & & & \\
\hline 3 & Competitive intensity & 2.82 & .44 & .01 & .03 & 1.0 & & & & & \\
\hline 4 & Strategy existence & 2.52 & .79 & $.08 * *$ & $.09 * *$ & $.06^{*}$ & .59 & & & & \\
\hline 5 & Strategy formalization & 1.91 & 1.10 & $.11 * *$ & $.14 * *$ & $.08 * *$ & $.65^{* *}$ & .72 & & & \\
\hline 6 & $\begin{array}{l}\% \text { wage bill on training } \\
\text { (Zscore) }\end{array}$ & 0.00 & 1.00 & .01 & .00 & .03 & .04 & $.07 * *$ & .03 & & \\
\hline 7 & $\begin{array}{l}\text { Training days/year- } \\
\text { management (Zscore) }\end{array}$ & 0.00 & 1.00 & -.01 & $.07 *$ & -.01 & $.10^{* *}$ & $.07^{*}$ & $.12 * *$ & .57 & \\
\hline 8 & $\begin{array}{l}\text { Training days/year } \\
\text { technical/prof. (Zscore) }\end{array}$ & 0.00 & 1.00 & -.02 & .04 & .00 & $.08 * *$ & $.07 *$ & $.14 * *$ & $.70 * *$ & .81 \\
\hline 9 & $\begin{array}{l}\text { Training days/year- } \\
\text { clerical (Zscore) }\end{array}$ & 0.00 & 1.00 & -.03 & $.06^{*}$ & .00 & $.10 * *$ & $.11^{* *}$ & $.14 * *$ & $.59 * *$ & $.68^{* *}$ \\
\hline 10 & $\begin{array}{l}\text { Training days/year- } \\
\text { manual (Zscore) }\end{array}$ & 0.00 & 1.00 & -.02 & .02 & -.00 & .05 & $.06^{*}$ & $.13^{* *}$ & $.45^{* *}$ & $.62 * *$ \\
\hline 11 & Feedback $360^{\circ}$ (Zscore) & 0.00 & 1.00 & .01 & -.00 & $.06^{*}$ & $.10^{* *}$ & $.12 * *$ & $.06^{*}$ & $.07 *$ & $.07 *$ \\
\hline 12 & $\begin{array}{l}\text { Incentives-managers } \\
\text { (Zscore) }\end{array}$ & 0.00 & 1.00 & .04 & .03 & $.08 * *$ & $.07 *$ & $.10^{* *}$ & $.07 * *$ & .04 & .04 \\
\hline 13 & $\begin{array}{l}\text { Incentives-tech/prof. } \\
\text { (Zscore) }\end{array}$ & 0.00 & 1.00 & $.06^{*}$ & .03 & .04 & $.07 * *$ & $.10^{* *}$ & $.10^{* *}$ & .04 & $.07 *$ \\
\hline 14 & $\begin{array}{l}\text { Incentives-clerical } \\
\text { (Zscore) }\end{array}$ & 0.00 & 1.00 & .03 & .01 & .04 & $.05^{*}$ & $.07 * *$ & $.12 * *$ & .03 & .05 \\
\hline 15 & $\begin{array}{l}\text { Incentives-manual } \\
\text { (Zscore) }\end{array}$ & 0.00 & 1.00 & .04 & $.06^{*}$ & .02 & .05 & $.08^{* *}$ & $.12^{* *}$ & -.01 & -.00 \\
\hline 16 & $\begin{array}{l}\text { Proportion workforce } \\
\text { part-time (Zscore) }\end{array}$ & 0.00 & 1.00 & .05 & .02 & -.00 & $.10^{* *}$ & $.10^{* *}$ & .04 & -.02 & -.04 \\
\hline 17 & $\begin{array}{l}\text { Change in workforce } \\
\text { part-time (Zscore) }\end{array}$ & 0.00 & 1.00 & .05 & .01 & .05 & $.08 * *$ & .05 & .01 & -.04 & -.05 \\
\hline \multirow[t]{2}{*}{18} & Perceived gross revenue & 4.0 & 1.13 & $.27 * *$ & $.14 * *$ & .02 & $.15^{* *}$ & $.16^{* *}$ & .03 & .02 & .03 \\
\hline & Variables & 9 & 10 & 11 & 12 & 13 & 14 & 15 & 16 & 17 & 18 \\
\hline 9 & $\begin{array}{l}\text { Training days/year- } \\
\text { clerical }\end{array}$ & .61 & & & & & & & & & \\
\hline 10 & $\begin{array}{l}\text { Training days/year- } \\
\text { manual }\end{array}$ & $.58 * *$ & .47 & & & & & & & & \\
\hline 11 & Feedback $360^{\circ}$ & .05 & .02 & .13 & & & & & & & \\
\hline 12 & Incentives-managers & -.01 & -.02 & $.34 * *$ & .67 & & & & & & \\
\hline 13 & Incentives-tech/prof. & .03 & -.01 & $.35 * *$ & $.79 * *$ & .86 & & & & & \\
\hline 14 & Incentives-clerical & .03 & .02 & $.29 * *$ & $.70 * *$ & $.82 * *$ & .80 & & & & \\
\hline 15 & Incentives-manual & -.01 & .05 & $.15^{* *}$ & $.49 * *$ & $.56^{* *}$ & $.69^{* *}$ & .42 & & & \\
\hline 16 & $\begin{array}{l}\text { Proportion workforce } \\
\text { part-time }\end{array}$ & $-.07 *$ & $-.08 * *$ & -.02 & $.10^{* *}$ & $.08 * *$ & $.08^{* *}$ & $.08^{* *}$ & .88 & & \\
\hline 17 & $\begin{array}{l}\text { Change in workforce } \\
\text { part-time }\end{array}$ & $-.08 * *$ & $-.07 * *$ & $.12 * *$ & $.21^{* *}$ & $.20^{* *}$ & $.17 * *$ & $.14^{* *}$ & $.51^{* *}$ & .30 & \\
\hline 18 & Perceived gross revenue & .03 & .02 & $.07^{*}$ & $.19^{* *}$ & $.16^{* *}$ & $.14^{* *}$ & $.13^{* *}$ & $.14 * *$ & .10 & 1.0 \\
\hline
\end{tabular}

* $(\mathrm{p}<0.05) ; * *(\mathrm{p}<0.01) \quad$ Note: Values in bold are squared multiple correlations for the indicators. Table 5 - Means, standard deviations and correlations among manifest variables. 


\begin{tabular}{|c|c|c|c|c|c|c|}
\hline Construct & $\begin{array}{c}\text { Compet. } \\
\text { Intensity } \\
\xi 1 \\
\end{array}$ & $\begin{array}{c}\text { Industry } \\
\text { Attract. } \\
\xi 2 \\
\end{array}$ & $\begin{array}{c}\text { Strategic } \\
\text { Manag. } \\
\eta_{1} \\
\end{array}$ & $\begin{array}{c}\text { Training } \\
\eta_{2}\end{array}$ & $\begin{array}{c}\text { Perfor. } \\
\text { Manag. } \\
\eta_{3} \\
\end{array}$ & $\begin{array}{c}\text { HR } \\
\text { Flexibility } \\
\eta_{4} \\
\end{array}$ \\
\hline $\begin{array}{l}\text { Strategic } \\
\text { Management } \\
\eta_{1}\end{array}$ & $\begin{array}{c}0.10 \\
2.69 * *\end{array}$ & $\begin{array}{c}0.22 \\
4.57^{* *}\end{array}$ & & & & \\
\hline $\begin{array}{l}\text { Training } \\
\eta_{2}\end{array}$ & & & $\begin{array}{c}0.12 \\
2.96^{* *}\end{array}$ & & & \\
\hline $\begin{array}{l}\text { Performance } \\
\text { Management } \\
\eta_{3}\end{array}$ & & & $\begin{array}{c}0.12 \\
3.58^{* *}\end{array}$ & & & \\
\hline $\begin{array}{l}\text { HR Flexibility } \\
\eta_{4}\end{array}$ & & & $\begin{array}{c}0.14 \\
2.84^{* *}\end{array}$ & & & \\
\hline $\begin{array}{l}\text { Organizational } \\
\text { Performance } \\
\eta_{5}\end{array}$ & & $\begin{array}{c}0.81 \\
7.50 * *\end{array}$ & & $\begin{array}{l}0.01 \\
0.45\end{array}$ & $\begin{array}{c}0.13 \\
4.69 * *\end{array}$ & $\begin{array}{c}0.10 \\
3.55^{* *}\end{array}$ \\
\hline
\end{tabular}




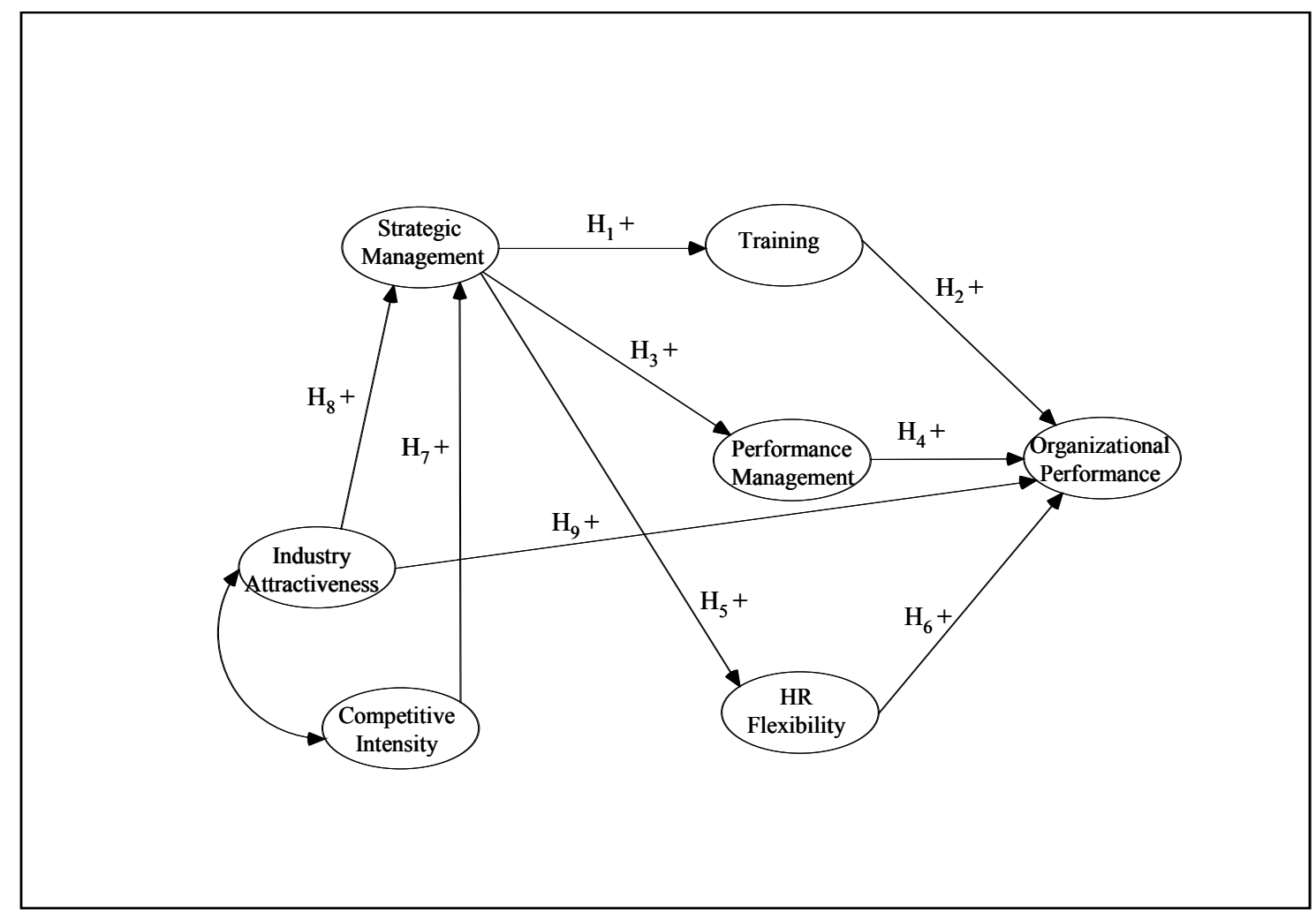

Figure 1 - Proposed model with hypotheses to be tested 


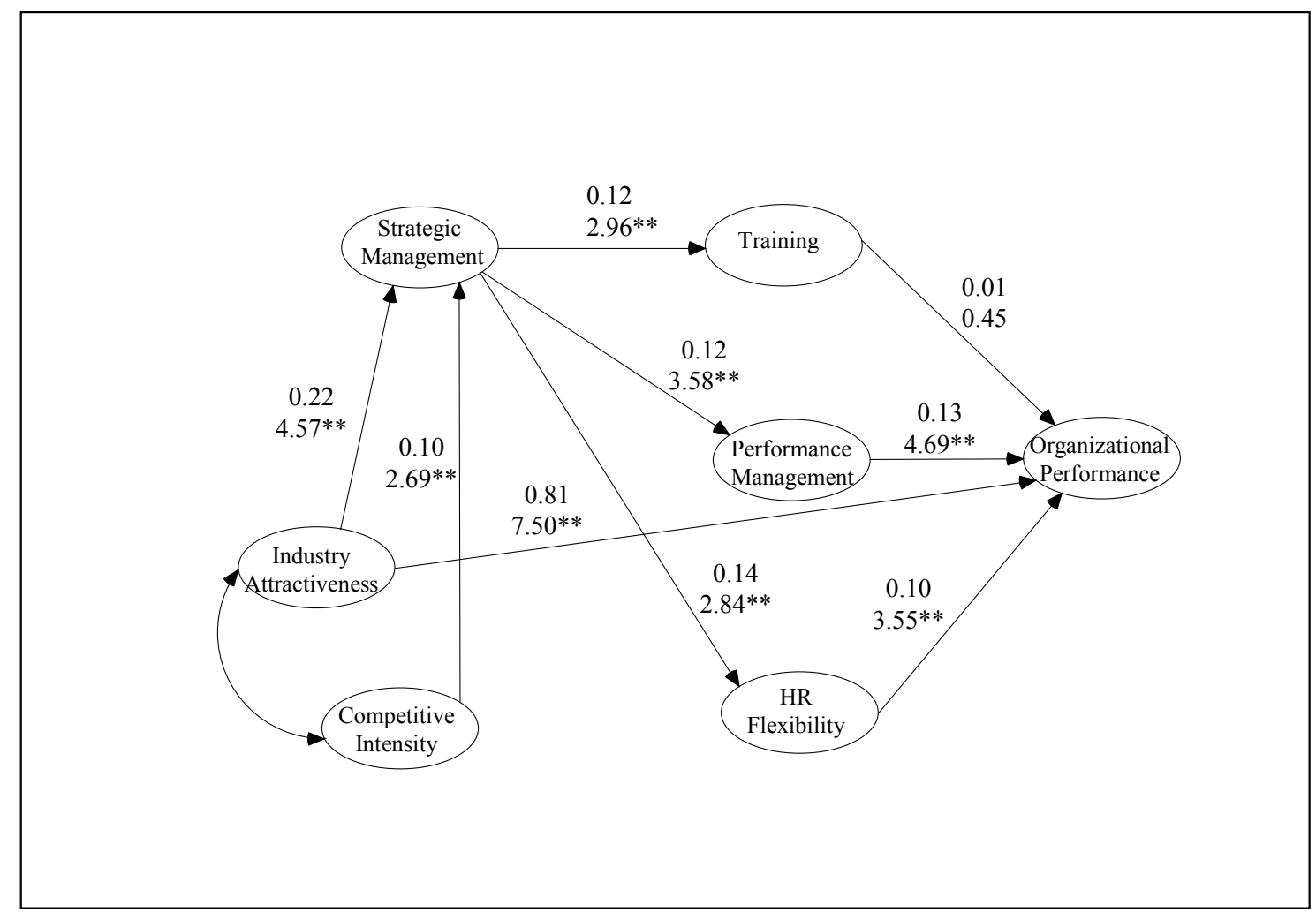

(Path coefficient values appear above t-values, $(* *) \mathrm{p}<0.01$ )

Figure 2 - Paths between latent variables (restricted model) 